\title{
Research Observation: Effects of rangeland ecological con- dition on scaled quail sightings
}

\author{
JAMUS JOSEPH, JERRY L. HOLECHEK, RAUL VALDEZ, MICHELLE COLLINS, AND MILT THOMAS
}

Authors are Graduate Student, Department of Animal and Range Sciences, New Mexico State University, Las Cruces, N.M. 88003; Professor, Department of Animal and Range Sciences, New Mexico State University, Las Cruces, N.M. 88003; Professor, Department of Fishery and Wildlife Sciences, New Mexico State University, Las Cruces, NM 88003; Graduate Student, Department of Fishery and Wildlife Sciences, New Mexico State University, Las Cruces, N.M. 88003; and Assistant Professor, Department of Animal and Range Sciences, New Mexico State University, Las Cruces, N.M. 88003.

\section{Abstract}

Scaled quail (Callipepla squamata) numbers were evaluated during and after a 2-year drought period using strip census techniques on 2 pastures in late seral rangeland ecological condition and 2 pastures in mid-seral rangeland ecological condtion. This study was conducted on the Chihuahuan Desert Rangeland Research Center (CDRRC) in south-central New Mexico on 4 adjoining pastures that were similar in size and terrain. During part of the study (August 1994 to April 1997) all 4 pastures were destocked due to depletion of perennial grass cover and biomass from a combination of drought and heavy cattle grazing. Scaled quail sightings pooled across sampling periods (9) were different $(P=0.08)$ on high and low rangeland ecological condition treatments. They averaged 10.72 birds per pasture on late-seral and 4.22 birds per pasture on mid-seral rangeland ecological condition treatments. Autumn perennial grass cover and standing biomass levels was higher $(P<0.10)$ on late seral than on mid-seral rangeland ecological condition pastures during both years of study. Availability of scaled quail foods such as leatherweed croton and broom snakeweed did not differ $(P>0.10)$ between treatments. Our study indicates that during extended dry periods livestock grazing at moderate intensities may adversely affect scaled quail populations in the Chihuahuan Desert by depleting perennial grass cover. However, in years of above average precipitation there is evidence scaled quail prefer mid-seral pastures over late-seral pastures. Maintaining a mosaic of conservatively (lateseral) and moderately (mid-seral) grazed pastures should best meet the habitat needs of scaled quail in the Chihuahuan Desert.

Key Words: upland game birds, wildlife, arid lands, cattle grazing, rangelands

Scaled quail (Callipepla squamata) are important upland game birds in the Chihuahuan Desert region of the southwestern United States and northern Mexico. However, a 50\% decline has occurred in scaled quail populations over their range during the past 30 years (Brennan 1993). Although reasons for the decline are not well understood, poorly controlled livestock grazing could be a contributing factor.

Research is lacking on how different cattle grazing intensities influence scaled quail populations in the Chihuahuan Desert.

This research was supported by the New Mexico Agr. Exp. Sta,m Kas Cruces, N.M. 88003 and was part of project 0172944.

Manuscript accepted 12 Sept. 02.

\section{Resumen}

El número de "Scaled quail" (Callipepla squamata) se evaluó durante y después de un periodo de sequía de 2 años mediante técnicas de censo en franjas, la evaluación se realizó en 2 potreros de condición ecológica del pastizal de etapa seral terminal y en 2 potreros de condición ecológica del pastizal de etapa seral intermedia. Este estudio se condujo en el Centro de Investigaciones de Pastizales del Desierto Chihuahuense (CDRRC) localizado en el centro-sur de New Mexico en 4 potreros adyacentes que fueron similares en tamaño y características del terreno. Durante parte del estudio (Agosto de 1994 a Abril de 1997) se removió completamente la carga animal de los cuatro potreros debido al abatimiento de la biomasa y cobertura de zacates perennes a causa de la combinación de la sequía y el fuerte apacentamiento por el ganado. Los avistamientos de "Scaled quail", promediadas a través de todos los periodos de muestreo (9), fueron diferentes $(P=0.08)$ en los tratamientos de condición ecológica de pastizal alta y baja. El promedio de aves por potrero fue de $\mathbf{1 0 . 7 2}$ en el tratamiento de condición seral final y 4.22 aves en el de condición seral intermedia. En ambos años del estudio, la cobertura de zacates perennes en otoño y los niveles de biomasa en pie fueron mayores $(P<0.10)$ en los potreros de condición seral final que en los de condición seral intermedia. La disponibilidad de alimento para el "Scaled quail", como "Leatherweed croton"y "Broom snakeweed", no difirieron (P > 0.10) entre tratamientos. Nuestro estudio indica que durante periodos de prolongada sequía el apacentamiento de ganado a intensidades moderadas puede afectar adversamente las poblaciones de "Scaled quail" en el desierto Chihuahuense al agotarse la cubierta de zacates perennes. Sin embargo, hay evidencia que años con precipitación arriba del promedio el "Scaled quail"prefiere potreros en condición ecológica de pastizal de etapas serales intermedias sobre los de condición seral final. Manteniendo un mosaico de potreros apacentados conservadoramente (condición seral final) y apacentados moderadamente (condición seral intermedia) debe ser lo mejor para satisfacer las necesidades de hábitat del "Scaled quail"en el desierto Chihuahuaense.

There is evidence that moderate grazing intensities may benefit scaled quail under some conditions by creating more structural diversity in plant communities with dense stands of grass (Campbell et al. 1973, Saiwana et al. 1998, Nelson et al. 1999). However, during drought periods even moderate livestock grazing may adversely impact scaled quail populations by depleting cover and food (Brown 1978). On early seral rangelands any benefits of livestock grazing on scaled quail habitat are doubtful 
(Saiwana et al. 1998). We compared the effects of late-seral and mid-seral rangeland ecological condition resulting from conservative and moderate cattle grazing on scaled quail sightings in southcentral New Mexico during and after a 2-year period of drought.

\section{Materials and Methods}

\section{Study Area Description}

Our 4 study pastures were located on the NMSU Chihuahuan Desert Rangeland Research Center (CDRRC) (32 $32^{\circ} 30^{\prime \prime} \mathrm{N}$ $\left.106^{\circ} 52^{\prime} 30^{\prime \prime} \mathrm{W}\right)$ operated by New Mexico State University, $37 \mathrm{~km}$ north of Las Cruces, N.M. in Dona Ana County. This flat to gently rolling area is in the southern portion of the Jornada del Muerto Plains between the San Andres Mountains to the east and the Rio Grande Valley to the west. Elevation varies from 1,188 to 1,371 $\mathrm{m}$. Soils of the Research Center are fine loamy, mixed, thermic, typic haplargids of the Simona-Cruces association (Soil Conservation Service 1980) underlain by calcium carbonate hard pan (caliche) at depths varying from a few centimeters to 1 $\mathrm{m}$ or more (Valentine 1970). In areas where the ground cover is sparse, sand dunes form around the invading mesquite (Prosopis glandulosa Torr.) plants (Wood 1969).

\section{Climate}

The climate on the Research Center is arid with an average of 200 days in the frost free period. The only permanent water sources are wells and pipelines provided for livestock use. Temperatures are high with a mean maximum of $36^{\circ} \mathrm{C}$ during June, and a mean maximum of $13^{\circ} \mathrm{C}$ during January (Pieper and Herbel 1982). Temperature differences are substantial between day and night. Strong winds in the spring cause severe erosion and water stress plants.

Annual precipitation is bimodal. Summer precipitation (July-September) is from localized convectional storms of high intensity, but low frequency. Winter precipitation (December-February) is relatively gentle and evenly distributed. Mean annual precipitation is $230 \mathrm{~mm}$ with $52 \%$ of the annual rainfall occurring during summer.

Annual precipitation in 1996 was 208 mm (89\% of $\bar{x}$ ) (Table 1). In 1994 and 1995 annual precipitation was $76 \%$ and $64 \%$ of the mean, respectively. Prior to the 1994-1996 period of below average precipitation, several years of above average precipitation had occurred.

Table 1. Average monthly precipitation $(\mathrm{cm})$ on the Chihuahuan Desert Rangeland Research Center in south central New Mexico for 1994 to 1998 period.

\begin{tabular}{|c|c|c|c|c|c|c|}
\hline Month & $\begin{array}{l}64 \text { yr. Avg } \\
1930-1998\end{array}$ & 1994 & 1995 & 1996 & 1997 & 1998 \\
\hline & \multicolumn{6}{|c|}{ 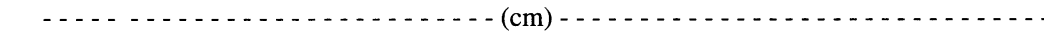 } \\
\hline Jan. & 1.27 & 0.76 & 1.65 & 0.71 & 1.47 & 0.38 \\
\hline Feb. & 1.04 & 0.30 & 0.97 & 0.10 & 1.63 & 0.91 \\
\hline Mar. & 0.66 & 0.35 & 0.05 & 0.00 & 1.55 & 1.04 \\
\hline Apr. & 0.55 & 0.55 & 0.00 & 1.55 & 0.28 & 0.13 \\
\hline May & 0.88 & 1.32 & 0.00 & 0.00 & 1.50 & 0.00 \\
\hline Jun. & 1.27 & 0.63 & 1.24 & 2.90 & 5.38 & 0.41 \\
\hline Jul. & 4.24 & 2.48 & 2.18 & 5.26 & 2.94 & 4.62 \\
\hline Aug. & 4.62 & 1.57 & 3.43 & 2.64 & 6.63 & 3.78 \\
\hline Sep. & 3.58 & 0.93 & 4.72 & 5.41 & 2.49 & 0.94 \\
\hline Oct. & 2.23 & 2.28 & 0.00 & 1.88 & 1.32 & 4.98 \\
\hline Nov. & 1.19 & 3.25 & 0.23 & 0.38 & 1.40 & 1.45 \\
\hline Dec. & 1.85 & 3.53 & 0.58 & 0.00 & 3.25 & 0.76 \\
\hline Total & 23.52 & 17.78 & 15.03 & 20.83 & 32.87 & 19.48 \\
\hline
\end{tabular}

\section{Vegetation}

Primary grass species on our study areas include black grama (Bouteloua eriopoda Torr.), dropseeds, (Sporobolus sp.), threeawns (Aristida sp.), bush muhly (Muhlenbergia porteri Kunth.), fluffgrass (Erioneuron pulchellum Tateoka), and tobosa (Hilaria mutica Buckley). The most commonly encountered shrub species is honey mesquite. It dominates the overstory and has been increasing over the past 100 years (Pieper and Herbel 1982). Other shrubs include broom snakeweed (Gutierrezia sarothrae Pursh), souptree yucca (Yucca elata av.), and creosotebush (Larrea tridentata [Pursh] Nutt.). Leatherweed croton (Croton pottsii Lam.) the primary forb, is an important food for livestock and pronghorn antelope (Antelocapra Americana).

\section{Experimental Procedures}

During 1991, 4 adjoining pastures arranged from west to east with similar soils (sandy loams), topography (flat), water availability and size $(1,098 \pm 126$ ha) were delineated and fenced. These pastures had previously (1970-1991) been grazed year-long at a moderate intensity by cow-calf pairs. At the beginning of our study in 1996 pastures 1 and 4 were in late seral ecological condition (57 and $64 \%$ of climax respectively) while pastures 2 and 3 were in mid seral ecological condition (37 and $32 \%$ of climax respectively) using the quantitative climax approach of Dyksterhuis (1949) (Nelson et al. 1997). In autumn 1992, 2 pastures (1 and 4) were stocked with cattle to obtain $30-35 \%$ use on key forage species while 2 pastures $(2$ and 3) were stocked to obtain $40-45 \%$ use of key species (Nelson et al. 1997). Cattle were removed from pastures due to drought from August 1994 to April 1997. Pastures were partially restocked in April 1997 and fully stocked to obtain $30 \%$ and $40 \%$ use levels in autumn of 1997 (Holechek 1988).

Foliar cover data were collected in autumn 1995, 1996, and 1997 at $10 \mathrm{key}$ areas spaced evenly across each pasture (Molinar 1999). Foliar cover on each key area was evaluated on 2, 61-m transects separate from those used for biomass evaluation. A modification of the line-intercept procedure of Canfield (1941) was used to determine percent foliar cover. A meter stick was used instead of an extended line. Measurements were made approximately every 6.1 meters along 2, $61 \mathrm{~m}$ transects at each key area. The meter stick was placed perpendicular to the transect and the intercept of the plants measured according to Bonham (1989). Standing crop biomass was also evaluated in autumn 1996 and 1997. Autumn forage standing crop was determined by clipping $20,0.5 \mathrm{~m}^{2}$ quadrats at $10-\mathrm{m}$ intervals along 2, 100-m lines on each key area.

In June 1993, 5 transects $1.6 \mathrm{~km}$ long were systematically placed in each pasture to monitor scaled quail densities (Nelson et al. 1997). With some exceptions transects were placed $1 \mathrm{~km}$ from boundary fences to minimize any ecotone effects where pastures adjoined. All transects were separated by at least $0.8 \mathrm{~km}$. Scaled quail sightings were recorded seasonally from winter 1996 through winter 1998 along the 5 transects in each of the 4 pastures using strip census techniques $(100 \mathrm{~m}$ $\mathrm{x} 1.6 \mathrm{~km}$ transects). Two observers walked adjacent transects within the same pasture on the same day. This technique was used due to the difficulties of enumerating scaled quail through standard line transect 
procedures (Brennan and Block 1986, Saiwana et al. 1998). Scaled quail typically run rather than hold or flush when encountered by people or dogs (Saiwana et al. 1998). Because of the chaotic nature of encounters, observers found it difficult to accurately measure sighting angles and distances to birds encountered. Two observers well trained in wildlife population sampling techniques walked transects. Each observer was limited to 2 transects per day. Observers rotated between grazing intensity levels on each sampling day (2 transects late-seral pasture, 2 transects mid-seral pasture). These inventories were taken seasonally from winter 1996 through spring 1998. Quail inventories were conducted between the hours of 0700 and 1100 . Only scaled quail observed within $50-\mathrm{m}$ on either side of the observer were recorded.

One problem with the enumeration technique we used is some birds previously counted can move ahead of the observer and potentially be counted again. The low level of quail encounters relative to distance traveled, the sparse nature of the vegetation, and the relatively flat terrain minimized this problem.

Brush cover was similar in height on the 4 pastures. However, ground visibility was impaired on the late-seral pastures where perennial cover was more dense and could have caused underestimation of scaled quail. Nevertheless, we believe our methods provided a reasonable estimation of relative quail numbers among pastures. All experimental pastures were open to hunting and all were equally accessible by roads. Autumn enumerations were made before hunting season.

\section{Statistical Analysis}

A repeated measures analysis of variance using the mixed model procedures of SAS (Littell et al. 1996) was used to compare scaled quail sightings across rangeland ecological condition levels (2), seasons (4), and years (2 years). This same type of analysis was used to compare standing herbage biomass and foliar cover among rangeland ecological condition levels (2) and years (2). Pastures 1 and 4 were used as replicates for late-seral treatments and pastures 2 and 3 were used as replicates for mid-seral treatments.

\section{Results and Discussion}

Scaled quail sightings pooled across seasons and years averaged 10.72 birds per pasture on late-seral (conservatively

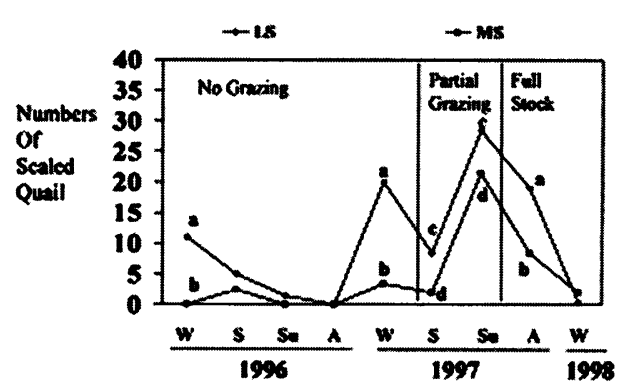

Fig. 1. Mean number of scaled quail observed per pasture on late-seral (LS) and mid-seral (MS) treatments on the Chihuahuan Desert Rangeland Research Center from winter 1996 to spring 1998. Pooled standard errors across treatments and time were \pm 3.99 quail per pasture. Letters a and $b$ differ $P<0.05$ and letters $c$ and $d$ differ $P<0.10$.

grazed) and 4.22 birds per pasture on midseral (moderately grazed) treatments $(\mathrm{P}=$ 0.08) (Fig. 1). Scaled quail sightings differed $(P=0.04)$ among years. Scaled quail sightings were higher in 1997 than 1996 when the same seasons were compared with the exception of spring. A total of 268 scaled quail were observed.

Autumn total vegetation cover and perennial grass cover differed between range condition treatments (Table 2).

condition treatments (Table 3). Perennial grass standing crop pooled across seasons and years averaged $213 \mathrm{~kg} \mathrm{ha}^{-1}$ on lateseral (conservatively grazed) and $172 \mathrm{~kg}$ $\mathrm{ha}^{-1}$ on mid-seral (moderately grazed) pastures. Year effect was significant $(P=$ 0.09 ) with autumn perennial grass standing crop lowest in the dry year of 1996 and highest in the wet year of 1997. The higher perennial grass standing crop in 1997 is related to $58 \%$ more precipitation

Table 2. Vegetation foliar cover (\%) on late-seral (LS) and mid-seral (MS) grazed pastures on the Chihuahuan Desert Rangeland Research Center in autumn 1995, 1996, 1997.

\begin{tabular}{|c|c|c|c|c|c|c|}
\hline & \multicolumn{2}{|c|}{1995} & \multicolumn{2}{|c|}{1996} & \multicolumn{2}{|c|}{1997} \\
\hline & $\overline{\mathrm{LS}}$ & MS & $\overline{\mathrm{LS}}$ & $\mathrm{MS}$ & $\overline{\mathrm{LS}}$ & $\mathrm{MS}$ \\
\hline & & & $--(\%$ & ver) - & & \\
\hline \multicolumn{7}{|l|}{ Grasses } \\
\hline$\overline{\text { Bouteloua eriopoda }}$ & $1.3^{\mathrm{a}}$ & $0.5^{\mathrm{b}}$ & $1.4^{\mathrm{a}}$ & $0.8^{\mathrm{b}}$ & $1.8^{\mathrm{a}}$ & $0.6^{\mathrm{b}}$ \\
\hline Sporobolus spp. & $1.0^{\mathrm{a}}$ & $0.4^{\mathrm{b}}$ & $0.6^{\mathrm{a}}$ & $0.2^{\mathrm{b}}$ & $1.1^{\mathrm{a}}$ & $0.3^{\mathrm{b}}$ \\
\hline Aristida spp. & $0.2^{\mathrm{a}}$ & $0.8^{\mathrm{b}}$ & $0.1^{\mathrm{a}}$ & $0.5^{\mathrm{b}}$ & $0.2^{\mathrm{a}}$ & $0.8^{\mathrm{b}}$ \\
\hline Other grasses & 0.4 & 0.1 & 0.1 & 0.1 & 0.7 & 0.2 \\
\hline Total grasses & $2.9^{\mathrm{a}}$ & $1.8^{\mathrm{b}}$ & $2.2^{\mathrm{a}}$ & $1.6^{\mathrm{b}}$ & $3.8^{\mathrm{a}}$ & $1.9^{\mathrm{b}}$ \\
\hline \multicolumn{7}{|l|}{ Forbs } \\
\hline Croton pottsii & 0.2 & 0. & 0.2 & 0.2 & 0.4 & 0.3 \\
\hline Other forbs & 0.8 & 0.8 & 0.2 & 0.4 & 1.6 & 0.1 \\
\hline Total forbs & 1.0 & 1.1 & 0.4 & 0.6 & 2.0 & 0.4 \\
\hline \multicolumn{7}{|l|}{$\underline{\text { Shrubs }}$} \\
\hline Gutierrezia sarothrae & 0.4 & 0.2 & 0.4 & 0.3 & 0.4 & 0.2 \\
\hline Prosopis glandulosa & 4.2 & 4.3 & 3.4 & 3.0 & 4.5 & 4.7 \\
\hline Other shrubs & $<0.1$ & $<0.1$ & $<0.1$ & $<0.1$ & $<0.1$ & $<0.1$ \\
\hline Total shrubs & 4.6 & 4.5 & 3.8 & 3.3 & 4.9 & 4.9 \\
\hline Total vegetation & $8.5^{\mathrm{a}}$ & $7.4^{b}$ & $6.4^{\mathrm{a}}$ & $5.5^{\mathrm{b}}$ & $10.7^{\mathrm{a}}$ & $7.2^{b}$ \\
\hline
\end{tabular}

${ }^{a, b}$ Rows within years with different letters differ $(\mathrm{P}<0.10)$.

Perennial grass cover $(\mathrm{P}=0.07)$ was higher on late-seral than mid-seral pastures in all 3 years of study. This also occurred for black grama and mesa dropseed cover. Other cover components showed no differences $(P>0.10)$ between grazing treatments. Year effects and year by treatment interactions were generally non-significant $(\mathrm{P}>0.10)$.

Total autumn standing crop of perennial grasses differed $(\mathrm{P}=0.04)$ between range than in 1996 (Table 1). Treatment by year interactions were not significant $(\mathrm{P}>0.10)$ for total perennial grass standing crop and biomass components with the exception of broom snakeweed $(P=0.09)$.

Range condition levels on the 4 pastures in our study were the same as in Nelson et al. (1997). However in contrast to our study, Nelson et al. (1997) reported average scaled quail sightings were twice as high on mid-seral compared to late-seral 
Table 3. Standing biomas $\left(\mathrm{kg} \mathrm{ha}^{-1}\right)$ on late-seral (LS) and mid-seral (MS) treatments in October 1996 and October 1997.

\begin{tabular}{lccccc}
\hline \hline & \multicolumn{2}{c}{1996} & & \multicolumn{2}{c}{1997} \\
\cline { 2 - 5 } Plant Species & $\mathrm{LS}$ & $\mathrm{MS}$ & & $\mathrm{LS}$ & $\mathrm{MS}$ \\
\hline Grasses & \multicolumn{2}{c}{$\left(\mathrm{Kg} \mathrm{ha}^{-1}\right)$} & & \multicolumn{2}{c}{$\left(\mathrm{Kg} \mathrm{ha}^{-1}\right)$} \\
Bouteloua eriopoda & $122^{\mathrm{a}}$ & $58^{\mathrm{b}}$ & & $139^{\mathrm{a}}$ & $100^{\mathrm{a}}$ \\
Sporobolus spp. & $38^{\mathrm{b}}$ & $48^{\mathrm{b}}$ & & $80^{\mathrm{a}}$ & $40^{\mathrm{b}}$ \\
Aristida spp. & $18^{\mathrm{b}}$ & $22^{\mathrm{b}}$ & & $21^{\mathrm{b}}$ & $58^{\mathrm{a}}$ \\
Other grasses & $4^{\mathrm{a}}$ & $6^{\mathrm{a}}$ & & $4^{\mathrm{a}}$ & $12^{\mathrm{a}}$ \\
Total grasses & $182^{\mathrm{c}}$ & $134^{\mathrm{d}}$ & & $244^{\mathrm{a}}$ & $211^{\mathrm{b}}$ \\
Forbs & & & & \\
Croton pottsii & $24^{\mathrm{c}}$ & $38^{\mathrm{bc}}$ & & $43^{\mathrm{ab}}$ & $51^{\mathrm{a}}$ \\
Other forbs & $29^{\mathrm{a}}$ & $27^{\mathrm{a}}$ & & $1^{\mathrm{b}}$ & $7^{\mathrm{b}}$ \\
Total forbs & $43^{\mathrm{a}}$ & $65^{\mathrm{a}}$ & $41^{\mathrm{a}}$ & $58^{\mathrm{a}}$ \\
Shrubs & & & & \\
Gutierrezia sarothrae & $28^{\mathrm{c}}$ & $50^{\mathrm{c}}$ & & $148^{\mathrm{a}}$ & $98^{\mathrm{b}}$ \\
Total vegetation & $258^{\mathrm{c}}$ & $249^{\mathrm{c}}$ & $433^{\mathrm{a}}$ & $367^{\mathrm{b}}$ \\
a,b Rows within years with different letters differ $(\mathrm{P}<0.10)$. & &
\end{tabular}

pastures in 1993 and 1994 (16.2 versus 8.1 birds, respectively; $\mathrm{P}=0.14$ ) (Fig. 2). Their study was at the end of a 10-yearperiod in which precipitation was about $30 \%$ above the long-term average. Perennial grass standing biomass was higher on the 4 pastures during their study than during ours because of several consecutive years of above precipitation (Nelson et al. 1997, Winder et al. 2000) (Fig. 2).

Moderate livestock grazing may benefit scaled quail populations in years of average or above average precipitation on Chihuahuan Desert rangelands in mid or late seral ecological condition (Campbell et al. 1973, Nelson et al. 1997, Saiwana et al. 1998). However, Brown (1978) reviewed evidence that scaled quail and several other gallinaceous gamebirds in arid environments can experience major population declines in drought years because of reduced cover and food. There is conjectural evidence these declines can be magnified by excessive livestock grazing (Brown 1978).

Scaled quail on our study pastures were seldom encountered in dense shrublands lacking perennial grass cover or in dense grassland areas devoid of shrubs. Scaled quail were primarily observed in areas with a mixture of mesa dropseed, black grama, threeawns, bare ground, broom snakeweed and scattered shrubs. Saiwana et al. (1998) and Nelson et al. (1999) made this same observation regarding scaled quail use of habitat in the Chihuahuan Desert. Mesa dropseed is a bunchgrass that grows to a $45-70 \mathrm{~cm}$ height with interspaces between individual plants. It is important in meeting the cover needs of scaled quail because it provides overhead concealment for scaled quail without obstructing their mobility (Saiwana et al. 1998). Mesa dropseed dominates Chihuahuan Desert sites in a mid to late seral stage while black grama dominates those in climax ecological condition (Holechek et al. 1994). Neither black grama nor mesa dropseed are important food sources for scaled quail (Davis and Banks 1973).

Both honey mesquite and broom snakeweed are

important scaled quail foods in New Mexico (Davis et al. 1975). Broom snakeweed and honey mesquite availability was not different between late-seral and midseral pastures (Table 2 and 3). Similarly forb availability did not differ $(\mathrm{P}>0.10)$ between treatments. Our data (Table 2) show perennial grass cover was the primary scaled quail habitat component that differed between late-seral and mid-seral pastures.

Since 1992 perennial grass cover and total vegetation cover on Chihuahuan Desert rangelands in southern New Mexico has been trending downwards due to several drought years (Galt et al. 1999). Perennial grass cover doubled between 1961 to 1992 due to average precipitation, but was reduced by $68 \%$ from 1992 to 1999 due to below average precipitation.

Our highest sighting of scaled quail occurred in summer 1997 (Fig. 1). In this period we observed a large proportion of small recently hatched birds. We attribute the higher number of quail sightings in summer and autumn 1997 compared to 1996 to more favorable precipitation in 1997. Campbell (1968) found scaled quail reproductive success in New Mexico was positively correlated with precipitation levels in April through August. We cannot well explain why relatively high scaled quail numbers were observed in winter 1997 and few scaled quail were observed in winter 1998. We believe this is probably a sampling aberration. Scaled quail coveys join together in late autumn to form large winter groups while they disperse into nesting pairs in early spring (Schemnitz 1961). The high numbers of scaled quail observed in winter 1997 in the late-seral treatment are the result of one chance encounter with large quail groups in pasture 1.

We recognize some limitations of our study. The 4 experimental pastures are contiguous and scaled quail can readily move from one pasture to another. Therefore, our data may more reflect scaled quail preference rather than actual survival and productivity under mid-seral and late-seral ecological condition levels. A useful follow up study would evaluate trends in scaled quail numbers on similar Chihuahuan Desert rangelands where lateseral and mid-seral treatments are widely separated.

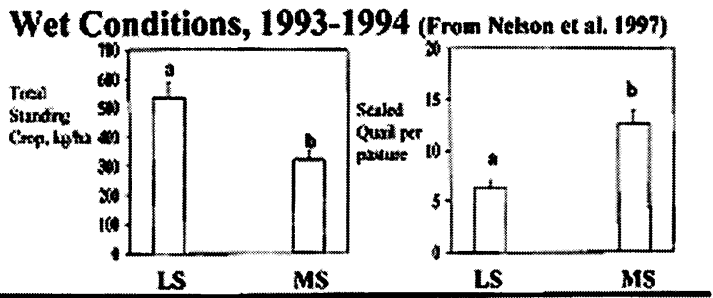

Dry Conditions, 1994-1997
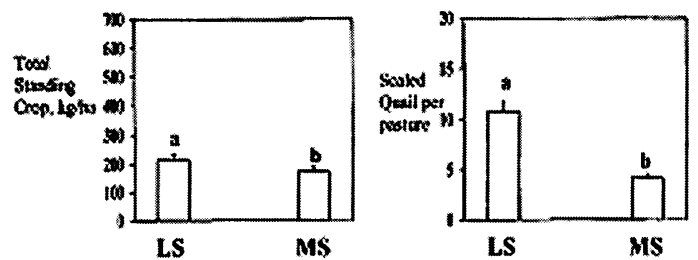

Fig. 2. Mean number of scaled quail observed per pasture and total standing crop of perennial grasses $\left(\mathrm{kg} \mathrm{ha}^{-1}\right)$ in pastures of late-seral (LS) and mid-seral (MS) ecological condition on the Chihuahuan Desert Rangeland Research Center. The years 1993-1994 were wetter than normal in the Chihuahuan desert (Nelson et al. 1997) and the years 1994-1997 were more dry than normal. Letters a and $b$ differ $P<0.05$. 


\section{Management Implications}

Our study indicates that extended dry periods and livestock grazing at moderate intensities may interact to adversely impact scaled quail populations in the Chihuahuan Desert through reduction in perennial grass cover and biomass. Conservative grazing has shown several benefits over moderate grazing in the Chihuahuan Desert. Benefits include: less soil erosion, accelerated plant succession, higher forage productivity, higher livestock productivity, higher financial returns, and lower ranching risk (Paulsen and Ares 1962, Valentine 1970, Holechek et al. 1994, 2000, Winder et al. 2000). Results from our study suggest that conservative grazing may improve habitat conditions for scaled quail during dry periods. During wet periods scaled quail appear to prefer moderately grazed pastures in mid seral condition while in dry periods they prefer conservatively grazed pastures in late seral condition. A mix of seral stages and grazing intensities should insure scaled quail habitat needs are best met.

\section{Literature Cited}

Bonham, C. D. 1989. Measurements for terrestrial vegetation. John Wiley and Sons. New York.

Brennan, L. A. 1993. Strategic plan for quail management and research in the United States: introduction and background Proceed. of the Nat. Bobwhite Quail Symp. 3:160-169.

Brennan, L. A. and W. M. Block. 1986. Line estimates of mountain quail density. J. Wildl. Manage. 50:373-377.
Brown, D. E. 1978. Grazing, grassland cover, and game birds. Trans. N. Amer. Wildl. Conf. 43:477-485.

Campbell, H. 1968. Seasonal precipitation and scaled quail in eastern New Mexico. J. Wildl. Manage. 32:641-644.

Campbell, H., D.K. Martin, P. E. Ferovich, and B. K. Harris. 1973. Effect of hunting and some other environmental factors on scaled quail in New Mexico. Wildlife Monogr. 34.

Canfield, R. H. 1941. Application of the line interception method in sampling range vegetation. J. Forest. 39:388-394.

Davis, C. A. and R. L. Banks. 1973. Some food habits of scaled quail in southeastern New Mexico. New Mexico State Univ. Agr. Exp. Bull 18

Davis, C. A., R. C. Barkley, and W. C. Haussamen. 1975. Scaled quail foods in southeastern New Mexico. J. Wildl. Manage. 39:496-502.

Dyksterhuis, E. J. 1949. Condition and management of rangeland based on quantitative ecology. J. Range Manage. 2:104-115.

Galt, D., J. Navarro, J. McCormick, and J. L. Holechek. 1999. Forty-six year trend in range condition in southwestern New Mexico. New Mexico State Univ. Agr. Exp. Sta. Livestock Res. Briefs. Las Cruces, N.M.

Holechek, J. L. 1988. An approach for setting the stocking rate. Rangelands 10:10-14.

Holechek, J. L., M. G. Thomas, D. Galt, and F. Molinar. 2000. Conservative and moderate stocking effects on Chihuahuan Desert forage production. Proc. West. Sec. Amer. Soc. Anim. Sci. 51:257-260.

Holechek, J. L., A. Tembo, A. Daniel, M. J. Fusco, and M. Cardenas. 1994. Long-term grazing influences on Chihuahuan Desert rangeland. Southwestern Naturalist 39:342-349.

Littell, R. C., G. A. Milliken, W. W. Stroup, and R. B. Woulfinger. 1996. SAS system for mixed models. SAS Inst., Cary, N.C.
Molinar, F. 1999. Soil depth effects on Chihuahuan Desert honey mesquite cover and forage production. Ph.D. Thesis, New Mexico State Univ., Las Cruces, N.M.

Nelson, T., J. L. Holechek, and R. Valdez. 1999. Wildlife plant community preference in the Chihuahuan Desert. Rangelands 21(1):9-11.

Nelson, T., J. L. Holechek, R. Valdez, and M. Cardenas. 1997. Wildlife numbers on late and mid seral Chihuahuan Desert Rangelands. J. Range Manage. 50:593-599.

Paulsen, H. A., Jr. and F. N. Ares. 1962. Grazing values and management of black grama and tobosa grasslands and associated shrub ranges of the southwest. USDA Forest Serv. Tech. Bull. 1270. Washington, D.C.

Pieper, R. D. and C. H. Herbel. 1982. Herbage dynamics and primary productivity of a desert grassland ecosystem. New Mexico Agr. Exp. Sta. Bull. 695.

Schemnitz, S. D. 1961. Ecology of the scaled quail in the Oklahoma panhandle. Wildl. Monogr. 8.

Saiwana, L., J. L. Holechek, A. Tembo, R. Valdez, and M. Cardenas. 1998. Scaled quail use of different seral stages in the Chihuahuan Desert. J. Wildl. Manage. 62(2):550-556.

Soil Conservation Service. 1980. Soil survey of Dona Ana County area. USDA, Las Cruces, New Mexico, USA.

Valentine, K.A. 1970. Influence of grazing intensity on improvement of deteriorated black grama range. New Mexico State Univ. Agr. Exp. Sta. Bull. 533.

Winder, J., C. C. Bailey, M. G. Thomas, and J. L. Holechek. 2000. Breed and stocking rate effects on Chihuahuan Desert cattle production. J. Range Manage. 53:32-39.

Wood, J. E. 1969. Rodent populations and their impact on desert rangelands. New Mexico State Univ. Agr. Exp. Sta. Bull. 555. 